\title{
Cultural Distance Revisited: Towards a More Rigorous Conceptualization and Measurement of Cultural Differences
}

\author{
Oded Shenkar \\ THE OHIo STATE UNIVERSITY
}

Cultural distance is a widely used construct in international business, where it has been applied to foreign investment expansion, entry mode choice, and the performance of foreign invested affiliates, among others. The present paper presents a critical review of the cultural dis-

$\mathrm{F}$ ew constructs have gained broader acceptance in the international business literature than cultural distance (CD). Presumably measuring the extent to which different cultures are similar or different, the construct has been applied to most business administration disciplines, i.e., management, marketing, finance and accounting. In management, $\mathrm{CD}$ has been used as a key variable in strategy, management, organization behavior and human resource management. The construct has been applied to a multitude of research questions, from innovation and organizational transformation to foreign expansion and technology transfer (Gomez-Mejia and Palich, 1997) and from affiliate performance to expatriate adjustment (Black and Mendenhall, 1991). It is in the area of foreign direct investment (FDI), how- tance construct, outlining its hidden assumptions and challenging its theoretical and methodological properties. A comprehensive framework for the treatment of the construct is developed and concrete steps aimed at enhancing rigor are delineated.

ever, that the construct has had its greatest impact.

To understand the appeal of the CD construct, it is useful to recall the nature of the phenomenon it is set to capture. Complex, intangible and subtle, culture has been notoriously difficult to conceptualize and scale (Boyacigiller, Kleinberg, Phillips and Sackmann, 1996). Establishing a measure gauging the "distance" between cultures has understandably presented an even greater challenge. By offering a seemingly simple and standardized measure of cultural differences, the CD construct offered a tangible and convenient tool with which to bypass the complexities and intricacies of culture, yielding a quantitative measure to be employed in combination with other "hard" data (see Kogut and Singh, 1988).

Oded Shenkar (Ph.D., Columbia University) is the Ford Motor Company Chair in Global Business Management at the Fisher College of Business, The Ohio State University.

JOURNAL OF INTERNATIONAL BUSINESS STUDIES, 32, 3 (THIRD QUARTER 2001): 519-535 
The appeal of the CD construct is, unfortunately, illusory. It masks serious problems in conceptualization and measurement, from unsupported hidden assumptions to questionable methodological properties, undermining the validity of the construct and challenging its theoretical role and application. Those problems, their implications and their remedies are the focus of the present paper.

\section{Cultural Distance in the Foreign INVESTMENT LITERATURE}

For almost three decades, CD and its proxies have been applied to multiple areas of business, from strategy to organization behavior to accounting and auditing, in both domestic and international contexts. The construct found its most loyal following in international business, where it has been used in such realms as foreign direct investment (FDI), headquarter-subsidiary relations, and expatriate selection and adjustment. By-and-large, FDI represents the most popular arena for the application of the CD construct, most often in the form of an index compiled by Kogut and Singh (1988) from Hofstede's (1980) cultural dimensions.

In the FDI literature, CD has had three primary thrusts. The first thrust has been to explain the foreign market investment location and especially the sequence of such investment by multinational enterprises (MNEs). The second, to predict the choice of mode of entry into foreign markets. A third application has been to account for the variable success, failure and performance of MNE affiliates in international markets. A brief review of each of those three thrusts follows.

\section{Cultural Distance and the Launch/Sequence of Foreign Investment}

The first use of CD in the FDI literature has been to account for the very decision of firms to invest in a foreign country. A theory of familiarity emerged, arguing that firms were less likely to invest in culturally distant markets. Yoshino (1976) and Ozawa (1979) viewed Japan's CD from Western nations as a constraint on Japanese FDI in the West. In a similar vein, Davidson (1980) attributed the large US investment in Canada and the UK -well beyond what their market size, growth, tariffs and proximity would have predicted- to cultural similarity. Dunning (1988), in contrast, argued that larger CD between home and host markets rather encouraged FDI as a way of overcoming transactional and market failures.

A related and eventually more influential use of the CD construct within the expansion stream has been to predict the sequence of multiple foreign entries. This work is closely associated with Johanson and Vahlne (1977), who observed that Swedish firms progressively expanded from their home base into countries with greater "psychic distance". This thesis has later become known as the Uppsala process model, or the "Scandinavian school" (Johanson and Wiedersheim-Paul, 1975; Luostarinen, 1980; Engwall, 1984; Welch and Luostarinen, 1988; Forgsren, 1989; Axelsson and Johanson, 1992). Support for the Scandinavian thesis has been limited (Thurnbull, 1987; Engwall and Wallenstal, 1988). Both Benito and Gripsrud (1992) and Sullivan and Bauerschmidt (1990) failed to find CD to be a predictor of FDI sequence per the Johanson and Vahlne thesis. 


\section{Cultural Distance and Entry Mode}

The Scandinavian school also predicted an incremental increase in investment commitment from exports into FDI. It was not clear whether the two trends -incremental distance and incremental commitment- were to occur in tandem, however, a first of many omissions in the area. Eventually, the thesis predicting relationship between CD and FDI mode has become synonymous with transaction cost theory (Wiliamson, 1985). The higher the $\mathrm{CD}$, the more control the MNE was likely to maintain over its foreign operations (Root, 1987; Davidson and McFeteridge, 1985; Kim and Hwang, 1992). Control was phrased as a choice between licensing and FDI but more often between the wholly owned subsidiary (WOS) and the partially controlled international joint venture (IJV) (Agarwal, 1994; Cho and Padmanabhan, 1995; Erramilli, 1991; Erramilli and Rao, 1993; Kogut and Singh, 1988; Larimo, 1993; Padmanabhan and Cho, 1994).

The loosening of control in culturally distant locations was seen as a way of reducing uncertainty and information costs (Alpander, 1976; Richman and Copen, 1972). As Goodnow and Hansz (1972, p. 46) put it, "degree of control declines as the environment becomes less favorable". In predicting entry mode, transaction cost theorists associate higher distance with a higher cost of transaction due to information costs and the difficulty of transferring competencies and skills (Buckley and Casson, 1976; Vachani, 1991). In transaction costs, internalization is imperative when market agents are likely to take advantage of a firm's limited knowledge and when future transaction contingencies could not be specified because of uncer- tainty or complexity (Williamson, 1975; Beamish and Banks, 1987). In the absence of internalization, it will not be possible to verify claims by agents and reduce operational uncertainty or reverse the investment all together (Williamson, 1981).

The underlying though implicit assumption in incorporating $C D$ into the transaction costs argument is that international operations are highly uncertain. Presumably, it will be more difficult to verify claims by culturally distant agents, since the agents will make claims rooted in an unfamiliar environment while buffered from enforcement by an MNE. Roth and O'Donnell (1996) argue that agency costs increase as a function of $\mathrm{CD}$ because complete and accurate information on agents'(subsidiaries') performance becomes more difficult and more costly to obtain, resulting in higher dependence of headquarters upon the subsidiary.

Gatignon and Anderson (1988) acknowledge that $C D$ does not fit very well within the transaction costs argument. Logically, the theory can accommodate opposite predictions of the CD-control mode relation. A firm may prefer low control to compensate for its lack of knowledge in high CD situations, relying on a local partner to contribute local knowledge. Or, it may opt for high control, i.e., a WOS, as a way of reducing dependence upon agents whose actions are poorly understood. Anderson and Gatignon (1986) suggest that high control is perhaps more efficient when the entrant's methods confer a transaction-specific advantage that cannot be easily imitated by other firms. "On occasion, operation methods that do not fit local culture will constitute the necessary advantage that enable foreigners to compete with locals on their home ground" 
(Anderson and Gatignon, 1986, p. 18). Indeed, from a resource-based perspective (Barney, 1991), the very ability to bridge $C D$ confers a unique advantage.

Empirical results regarding the impact of $C D$ on entry mode are mixed (Benito and Grisprud, 1992; Padmanabhan and Cho, 1994). Eramilli and Rao (1993) found that low $\mathrm{CD}$ resulted in low control, though the relationship was mediated by level of experience and asset specificity. Pan (1996) found that the larger the $C D$, the more likely it was for a foreign partner to have an equal or a majority stake in their Chinese IJV. Boyacigiller (1990) found that CD was positively related to control (defined as the proportion of US nationals in the foreign affiliate). On the other hand, Kogut and Singh (1988) and Kim and Hwang (1992) report low control modes at high CD levels. Kogut and Singh (1988) found that greater CD increased the likelihood of green-field IJVs over both green-field WOSs and the acquisition of a controlling stake in an existing operation. While the contradictory results can be partially attributed to the firms studied (the service firms examined by Erramilli and Rao and Boyacigiller could have lower control costs than the manufacturing enterprises researched by Kim and Hwang and Kogut and Singh), this is unlikely to explain the full spectrum of inconsistent results.

\section{Cultural Distance and Affiliate Performance}

In this third application, $C D$ has largely been taken to represent a hindrance to the performance of the MNE and its affiliates. According to Chang (1995), CD limits the ability of a MNE to generate rent when entering new domains. Empirical results have been mixed. Li and Guisinger (1991) found that US affiliates whose foreign partners came from culturally dissimilar countries were more likely to fail. Barkema, Shenkar, Vermeulen and Bell (1997) found that firms which have gradually ventured into more culturally distant locations were less likely to have their affiliates terminated prematurely; controlling for experience, IJV longevity decreased with the CD to the host country. Johnson, Cullen and Sakano (1991) reported that "cultural congruence" between IJV partners had no effect on the Japanese partner's perceptions of success, and Park and Ungson (1997) found that a larger CD was actually associated with lower rate of JV dissolution.

\section{Hidden Assumptions in the Cultural Distance Construct}

The inconsistent results obtained for the three FDI thrusts may be the result of the conceptual and/or methodological properties of the CD construct. In this section, these properties are culled from an extensive review of the literature applying the CD construct to the domain of FDI and enriched with insights from the broader literature on culture, FDI, and related areas. The properties are presented in the form of hidden assumptions that largely go unnoticed but are not supported by either logic or empirical evidence.

The hidden assumptions appear in two clusters, one emanating from the conceptual properties of the construct, the other from its methodological properties. Conceptual properties produce illusions that are the core of the CD construct and undermine its validity within the context of FDI theories. Methodological properties present instrumentation and measurement biases that distort the accurate measurement of cultural differences; they are most closely associated 
with the Kogut and Singh (1988) index but address broader measurement issues as well. While the two sets of properties are intertwined, they represent distinct sets of problems that require different sets of remedies and are hence presented in separate clusters.

\section{Conceptual Properties}

The Illusion of Symmetry. "Distance", by definition, is symmetric: The distance from point $A$ to point $B$ is identical to the distance from point $B$ to point $A$. CD symmetry is however difficult to defend in the context of FDI. It suggests an identical role for the home and host cultures, for instance, that a Dutch firm investing in China is faced with the same CD as a Chinese firm investing in the Netherlands. There is no support for such an assumption. Numerous studies have shown the importance of investor culture in predicting investment, entry mode and performance (e.g., Pan, 1996; Kogut and Singh, 1988; Tallman, 1988). Other studies have shown a role for the host culture. However, there are no studies showing symmetry between the two nor is there a reason to assume one. On the contrary, home and host country effects are different in nature, the former being embedded in the firm while the latter is in a national environment.

The Illusion of Stability. Measured at a single point in time, CD is implicitly assumed to be constant. Cultures change over time, however. The culture measured at market entry time may have changed by the time performance is measured. Further, a convergence thesis (Webber, 1969) would predict CD narrowing over time as more investors flock into the market and local employees become knowledgeable of MNE management methods (Richman and Copen, 1972). As firms learn more about a mar- ket, their CD to that market decreases. Stopford and Wells (1972) found that when a firm had more experience in a country, it was more likely to choose a WOS that an IJV (see also Dubin, 1975). Hennart (1991) found that experience in the US has led Japanese firms to look more favorably at a WOS than at an IJV. International experience may also lead firms to prefer acquisition to green-field investment (Caves and Mehra, 1986), a preference which is not captured by the control thesis yet significantly influences the availability of WOS versus IJV investment.

The Illusion of Linearity. Also embedded in the distance metaphor is the assumption of linear impact on investment, entry mode and performance. The higher the distance between cultures, the higher the likelihood that (a) investment will occur at a later stage in the investment sequence, (b) a less controlling entry mode will be chosen, and (c) the worse the performance of foreign affiliates will be. These are all questionable assumptions. On the contrary, the Scandinavian school acknowledges that the time lag between expansion waves will vary due to differences in learning curves. Erramilli (1991) showed that CD and experience interacted to influence ownership in a nonlinear fashion. Davidson (1980) suggested that firms taking their first investment steps were more likely to prefer culturally similar countries than those in an advanced stage of internationalization (see also Bilkey, 1978). Pan (1997) found that foreign partners who already held a majority equity stake in a JV were not interested in further increasing this stake when CD was large.

Parkhe (1991) points out that CD, like other "diversity variables", plays a different role at the strategic choice and 
operational phases. At the strategic phase, cultural differences may be a basis for synergy while at the operational phase they may erode the applicability of the parent's competencies (see also Brown, Rugman and Verbeke, 1989; Chowdury, 1992; Gomes-Casseres, 1989; Harrigan, 1985, 1988; Hergert and Morris, 1988; Lorange and Roos, 1991). The expatriate literature suggests that adaptation to a foreign culture may be Ushaped (Black and Mendenhall, 1991) and reports that adjustment to a relatively similar culture is often as difficult as adjustment to a "distant" one because differences are not anticipated (e.g., Brewster, 1995; O’Grady and Lane, 1996).

The Illusion of Causality. Implicit assumption in much of the literature is that CD has a causal effect on FDI pattern, sequence and performance. The connotation is that culture is the only determinant of distance with relevance to FDI. Earlier work has been tuned to the problem and attempted to compensate by incorporating non-culture variables in a broader "distance" measure. Johanson and Vahlne's (1977) definition of "psychic distance" refers to the "sum of factors" affecting information to the market. Goodnow and Hansz (1972) treat "geocultural distance" as one of a number of variables (also including level of development, political stability), making a country a "hot" or "cold" investment opportunity. Richman and Copen's (1972) measure of "socio-cultural distance" includes such variables as the foreign education of local executives.

As Boyacigiller (1990, p. 363) offers, "key characteristics of nations such as dominant religion, business language, form of government, economic development and levels of emigration to the US indicate a country's cultural distance from the US". Factors such as language (Buckley and Casson, 1976, 1979) political instability (Thunnell, 1977), level of development, market size and sophistication (Davidson and McFetridge, 1985) all play a role in establishing "distance". Barkema et al. (1997), in their study of the FDI of Dutch firms, found the effect of CD to be significant for IJVs in developing countries, but not for IJVs in developed countries. A similar point is made by Beamish (1993) vis-a-vis investment in China's transitional economy. Brown, Rugman and Verbeke (1989) argue that the combination of economic and cultural factors creates firm specific assets, which can cause failure.

The Illusion of Discordance. The implicit assumption that differences in cultures produce lack of "fit" and hence an obstacle to transaction is questionable. First, not every cultural gap is critical to performance. As Tallman and Shenkar (1994, p. 108) note, "different aspects of firm culture may be more or less central, more or less difficult to transmit, and more or less critical to operations". Second, cultural differences may be complementary and hence have a positive synergetic effect on investment and performance. For instance, as global cooperation demands both concern for performance (masculine) and concern for relationships (feminine), the two may be mutually supportive (Hofstede, 1989; Haspeslagh and Jemison, 1991). Similar evidence can be found in the FDI (Barkema and Vermeulen, 1998), merger and acquisition (e.g. Haspeslagh and Jemison, 1991; Morosini, 1998) and IJVs literature (Shenkar and Zeira, 1992).

\section{Methodological Properties}

The Assumption of Corporate Homogeneity. The CD index used to measure the construct relies on national culture 
measures and implicitly assumes lack of corporate culture variance, an assumption that lacks support (e.g., Hofstede, Neuijen, Ohavy and Sanders, 1990). Laurent (1986) proposes that corporate culture can modify the behavior and beliefs associated with national culture, a proposition confirmed by Weber, Shenkar and Raveh (1996) for international mergers. Corporate culture alters the dynamics of national CD though not necessarily in the way of reducing its impact. As Schneider (1988) notes "national culture may play a stronger role in the face of a strong corporate culture. The pressures to conform may create the need to reassert autonomy and identity, creating a national mosaic rather than a melting pot”.

The Assumption of Spatial Homogeneity. Measuring distance from one national culture to another, the CD index assumes uniformity within the national unit. Quite to the contrary, evidence suggests that intra-cultural variation explains as much if not more than intercultural variation ( $\mathrm{Au}, 2000)$. Neither the spatial location of the firm in the home or host country nor the actual physical distance between the locations, have an impact upon the CD measure calculated. This masks actual investment conditions, for instance a "border effect" formed across contiguous regions divided by a national border (Mariotti and Piscitello, 1995). A somewhat similar argument can be made regarding the variable location of industries from the cultural milieu, as, for instance, in the case of "cultural industries".

The Assumption of Equivalence. The Kogut and Singh (1988) index is a rather simplistic aggregate of Hofstede's (1980) dimensions and is hence liable to the same criticism leveled against Hofstede, e.g., non-exhaustiveness, reliance on sin- gle company data, and the like (e.g., Schwartz and Bilsky, 1990; Schwartz, 1994; Drenth, 1983; Goodstein and Hunt, 1981). The index amplifies the problems associated with the Hofstede framework in two important ways, however.

First, the index has not been updated to incorporate latter work by Hofstede and others, for instance, the fifth dimension of Confucian dynamism or Long Term Orientation (LTO) (Hofstede and Bond, 1988). Derived from a Chinese instrument, this dimension captures a facet that is critical to corporate strategy. Because of its relationship to Confucianism, CD measures involving East-Asian countries, for instance, those used in studies of Japanese FDI (e.g., Yoshino, 1976; Ozawa, 1979; Li and Guisinger, 1991), are especially open to challenge.

The second and most important way in which the Kogut \& Singh's measure amplifies the measurement problems associated with Hofstede is by making an invalid assumption of equivalence. Hofstede (1989) offers that some cultural gaps are less disruptive than others, and that differences in uncertainty avoidance are potentially the most problematic for international cooperation due to their correlates in terms of differential tolerances towards risk, formalization, and the like. Kogut and Singh (1988) themselves examined the role of Uncertainty Avoidance separately from their index. Both Barkema et al (1997) and Barkema and Vermeulen (1998) supported Hofstede's (1989) contention and found that uncertainty avoidance was more important than other cultural dimensions in predicting FDI success. Other studies have shown individualism to have a special effect on FDI (e.g., Hamel, Doz and Prahalad, 1989; Shane, 1992; Dickson and Weaver, 1997). The aggregate measure may hence provide false readings 
regarding meaningful cultural differences.

\section{INTEGRATION AND CONSTRUCT DEVELOPMENT}

The significant conceptual and methodological inadequacies relating to the CD construct carry important implications for theory and research. For example, the illusion of symmetry pinpoints divergent transaction costs and the prospect of conflict between partners as each seeks to minimize its cost of the transaction regardless of the cost incurred by the other party; necessitating convergence of transaction and bargaining models. By showing that certain cultural combinations possess synergetic rather than disruptive potential, the illusion of discordance may explain the inconsistent results obtained for the transaction cost argument regarding control and performance. The illusion of causality may explain the inconsistent results obtained for $\mathrm{CD}$ and FDI sequence. For instance, Benito and Gripsrud (1992) proposed that their lack of support for the gradual expansion thesis might have been the result of similarity in labor costs among countries within the same cultural cluster. The assumption of spatial homogeneity may explain obtaining inconsistent results for the same pair of countries.

In the following pages, an integrative framework for the treatment of CD construct is developed. In a departure from the existing metaphor that is focused on what sets cultures apart, we also consider mechanisms closing CD. Then, we incorporate a crucial yet missing element in the current conceptualization of $\mathrm{CD}$, namely the interface among transacting parties and its accorded friction. Taken together, the two serve to form a basis from which a comprehensive framework for the treatment of the CD construct is launched.

\section{Closing Cultural Distance}

A product of the use of a metaphor can be the framing of one's frame of reference (Morgan, 1986). In the case of CD, the "distance" metaphor is translated into a focus on what sets cultures apart but not on what might bring them together. A balanced analysis of the relations between social entities should however consider both opening and closing mechanisms. A number of key mechanisms with the potential of closing cultural distance follow.

Globalization and Convergence. Increased communication and interaction bridge $\mathrm{CD}$ by encouraging the convergence of cultural systems (Webber, 1969). This implies a trend towards lower $C D$ over time albeit at different paces across the globe. The World Competitiveness Yearbook (2000) publishes an index of openness to foreign influences showing substantial differences between relatively open countries such as The Netherlands to closed countries such as France and Korea.

Geographical proximity. Often confused with CD (as in the case of Canada as a first foreign investment for East- and Mid-West US firms), geographic proximity reduces entry barriers (Buckley and Casson, 1979; see also Mariotti and Piscitello), subject to transportation and information processing requirements. Geographical proximity lowers the costs of managerial coordination and control and reduces the cost of monitoring agent's behavior. It can also facilitate the personal contact that is necessary for effective transfer of knowledge and other resources (Vachani, 1991).

Foreign Experience. The literature acknowledges the importance of foreign 
experience as a CD closing mechanism. It is not always clear however whether it is international experience per se or experience in the host culture and to what extent the experience of individual managers can substitute for corporate experience, a point that would be especially important to smaller firms (see also \#acculturation).

Acculturation. Acculturation has been defined (Berry, 1980) as "changes induced in systems as a result of the diffusion of cultural elements in both directions". Acculturation can generally be assumed to reduce the $\mathrm{CD}$ to the host country. It is interesting that in explaining one exception to the pattern of gradual involvement they observed (the establishment of a sale subsidiary in a new market), Johanson and Vahlne (1977) explain that the decision-maker in that case was partly educated in the other country. Nor is acculturation dependent upon actual experience. Black, Mendenhall and Oddou (1991, p. 310) suggest that "individuals make anticipatory adjustments before they actually encounter the new situation". Corporations may do the same, in effect closing the CD to a country even prior to the establishment of operations there. Another intriguing question is whether the reentry syndrome described by Adler (1981) would apply at the corporate level.

Cultural Attractiveness. Certain cultures are considered attractive to other cultures. A foreign culture's perceived attributes may be a major reason for the preferences expressed by potential partners and host countries (Gould, 1966). From a cognitive perspective (Sackmann, 1983; Boyacigiller et al., 1996), even when attractiveness is absent, adjustment to a relatively similar culture is often as difficult as adjustment to a "distant" one. This is explained by the expa- triate literature in that expatriates do not expect differences in relatively similar cultures (e.g., Brewster, 1995; O’Grady and Lane, 1996).

Staffing. Staffing is not only a means of control but also a venue through which groups and individuals bring their cultural properties into a system. Shenkar (1992) discusses the role of employee groups as mechanisms affecting the national and corporate CD in an IJV. For instance, foreign parent expatriates bring with them both the national and corporate culture of the parent while third country nationals recruited by the foreign parent will likely bring the parent firm's culture into the venture, but less of its national culture. The M\&A literature make the point that such senior managers have a major influence on the motivation of the other employees and play the most significant role in shaping and transmitting corporate culture signals to the broader membership (see Weber, Shenkar and Raveh 1996). Bicultural individuals play an especially important role in closing the CD between the foreign and host countries. By virtue of their familiarity with both cultures, such individuals bring the two countries together by serving as emissaries and interpreters of culturally embedded signals and behaviors. The presence of such individuals in a company, especially in senior positions, may hence serve as a mechanism closing CD.

\section{Cultural Interaction as Friction}

While the existence of mechanisms opening and closing CD can be accommodated within the "distance" metaphor, a closer look into the reality of FDI points at interaction as the key issue. After all, how different one culture is from another has little meaning until those cultures are brought into contact 
with one another. Hence, we suggest replacing the "distance" metaphor with that of "friction", the term used by Williamson (1975) in his original treaty on transaction costs theory. By friction, we mean the scale and essence of the interface between interacting cultures, and the "drag" produced by that interface for the operation of those systems.

As an example, let us consider the difference in the cultural interface between an IJV and an international M/A. An IJV is, by definition, an entity separate from its parent firms. While the patents maintain direct contact as well, the bulk of the interaction is mediated by the IJV whose activities remain compartmentalized from those of the parents. The cultural differences between the parent firms produce friction only to the extent of their involvement with the new entity. Individuals and units in the parent firms who are not involved with the IJV operations do not produce friction. In contrast, a merger brings together the entire set of operations on both sides, producing, at least on the onset, much greater friction. In many M\&As, integration is a key goal (see Weber et al., 1996, for a summary). The intense interaction makes it more dramatic, and the ensuing conflict makes differences salient (Sales and Mirvis, 1984). Weber, et al. (1996) found that the top managers in acquired firms have made anticipatory adjustment towards the acquiring organization. In contrast, officers of the acquiring firm may find little reason to do the same.

Obviously, friction varies within the M\&A population as well. Where the acquiring firm determines goals, strategic choices and other operations for the acquired company, more friction can be initially expected, but such friction may decline faster than where each firm retains its autonomy. "Modes of accultur- ation", such as integration, assimilation, separation and deculturation (Nahavandi and Malekzadeh, 1988) will hence influence friction levels. For similar reasons, friction is also likely to differ between acquisition and green-field investment. In an acquisition, the potential friction is greater, because the acquired firm has already a corporate culture in place. Indeed, lower $C D$ was found to increase the rate of acquisitions over green-field investments (Dubin, 1975), while high CD has been suggested as a reason why Japanese investors in the US prefer green-field investments and partial over complete acquisitions (Hennart, 1991). Li and Guisinger (1991), among others, report that foreign acquisitions of US firms tend to fail more than greenfield investment, possibly the result of cultural friction.

The friction among cultural systems is also the product of strategic objectives, that is, how closely do firms want the other system to be positioned vis-à-vis their own. The tighter the control to be maintained, the greater the friction potential. Hence, control (and, in extension, entry mode) is not only the product of cultural "distance", it is also a potential trigger of cultural friction. Further, culture itself is a means of control (Schneider, 1988). A strong corporate culture could, in theory, lower the transaction cost as the subsidiary becomes similar to the parent, though results by Laurent (1986) suggest that corporate culture actually accentuates national culture differences.

\section{Recommendations}

While the theory development effort delineated earlier will eventually result in new $C D$ measures, a number of key steps can be taken now, as follows. First, the Kogut and Singh (1988) index must 
be supplemented by Long Term Orientation (Confucian Dynamism) especially where East-Asian countries are involved. The use of the aggregate index must be theoretically justified and where appropriate, substituted by CD measures calculated separately for one or more of the five dimensions as necessitated by theoretical and domain considerations. Both aggregate and one-dimensional measures should also be drawn from alternative classifications, e.g., Schwartz' (1994) with multiple measures employed wherever possible.

Second, measures of general cultural similarity such as Ronen and Shenkar's (1985, for applications see Barkema et al., 1997; Park and Ungson, 1997; Vachani, 1991), which do not assume linearity, additivity and normal distribution should be used in conjunction with other measures. Findings showing relationship between CD and governance for select country clusters (e.g., Gatingnon and Anderson, 1988) suggest supplementing those approaches with measures of cultural diversity such as Gomez-Mejia and Palich's (1997) indices of inter-cluster and intra-cluster diversity.

Third, national level data should be supplemented by cognitive CD measures (e.g., Sullivan and Bauerschmidt, 1990). An example can be found in Boyacigiller (1990), where executives were asked to rank adjustment difficulties in countries where they had served in the past. Retrospective data should be considered in deriving such cognitive measures. Evidence suggests such data do not become less accurate over time periods as long as ten years (Finkelstein, 1992; Huber and Power, 1985) and are especially helpful when anchored in dramatic events such as mergers that tend to make culture and cultural differences more salient. A recent example can be found in Veiga, Lu- batkin, Calori and Very (2000; see also Veiga, Lubatkin, Calori, Very and Tung, 2000). Qualitative, emic data should be added wherever feasible.

Fourth, control for closing distance mechanisms such as cultural attraction, acculturation and foreign experience, geographical distance (Balabanis, 2000), language, level of development, home market and company size (Erramilli, 1996) which have already been found to correlate with CD or to mediate or moderate its impact on FDI. Control for CD at the corporate level using the wide repertoire of corporate culture instruments while remaining aware of both instrument design (Geringer, 1998) and interaction effects (Weber et al., 1996) across the two levels.

Fifth, consider CD not only as an independent variable predicting FDI governance, sequence and performance (or other variables as the case may be) but also as a dependent variable. $\mathrm{CD}$ is as much the product as the consequence of entry mode, and FDI sequence and even performance may have an impact on the perceived distance. Consider culture also as a quasi-moderator variable altering the form if not the strength of the relationship between environmental and strategic variables.

Finally, consider cultural differences as having the potential for both synergy and disruption (Morosini, 1998; Parkhe, 1991). This point cannot be overstated as it lies at the intersection of strategic logic and operational challenges that underline the FDI, expatriate adjustment, auditing and other international business issues. Replacing the "distance" with "friction" as the underlying metaphor for cultural differences is a natural step from there. Not merely semantic, this implies focusing on the interface between trans- 
acting entities rather on the void between them.

\section{REFERENCES}

Adler, N. J. 1981. Re-Entry: Managing Cross-Cultural Transitions. Group and Organization Studies, 6:341-356.

Agarwal, S. 1994. Socio-Cultural Distance and the Choice of Joint Ventures: A Contingency Perspective. Journal of International Marketing, 2(2): 63-80.

Alpander, G.G. 1976. Use of Quantitative Methods in International Operations by U.S. vs. Overseas Executives. Management International Review, 16(1): 71-77.

Anderson, E.\& H. Gatignon. 1986. Modes of Foreign Entry: A Transaction Cost Analysis and Propositions. Journal of International Business Studies, 17(2): 1-26

$\mathrm{Au}, \mathrm{K} . Y$. 2000. Inter-Cultural Variation as Another Construct of International Management: A Study Based on Secondary Data of 42 Countries. Journal of international management, 6, 217-238.

Axelsson, B. \& Johanson, J. 1992. Foreign Market Entry-The Textbook Versus the Network View. In. B. Axelsson \& G. Easton (eds.), Industrial Networks: A New View of Reality. London, UK: Routledge, 218-234.

Balabanis, G. I. 2000. Factors Affecting Export Intermediaries' Service Offerings: The British Example. Journal of International Business Studies, 31, 1, 83-99.

Barkema, H., Shenkar, O., Vermeulen, F. \& Bell, J.H. 1997. Working Abroad, Working with Others: How Firms Learn to Operate International Joint Ventures. Academy of Management Journal, 40, 2, 426-442.

\& Vermeulen, F. 1998. International Expansion through Start-Up or
Acquisition: A Learning Perspective. Academy of Management Journal, 41(1): 7-26.

Barney, J. B. 1991. Firm Resources and Sustained Competitive Advantage. Journal of Management, 17 (1): 99-120.

Beamish, P. 1993. The Characteristics of Joint Ventures in the People's Republic of China. Journal of International Marketing, 1, 2, 29-48. and Banks, J.C. 1987. Equity Joint Ventures and the Theory of the Multinational Enterprise. Journal of International Business Studies (summer), 1-16

Benito, R.G. \& Gripsrud, G. 1992. The Expansion of Foreign Direct Investments: Discrete Rational Location Choices or a Cultural Learning Process? Journal of International Business Studies, 3, 461-476.

Berry, J.W. 1980. Social and Cultural Change. In Triandis H.C. \& Brislin R.W. (Eds.), Handbook of Cross-Cultural Psychology (Volume 5, pp. 211279). Boston: Allyn \& Bacon.

Bilkey, W.J. 1978. An Attempted Integration of the Literature on the Export Behavior of Firms. Journal of International Business Studies, 9, 33-46.

Black, J.S. \& Mendenhall, M. 1991. The U-Curve Adjustment Hypothesis Revisited: A Review and Theoretical Framework. Journal of International Business Studies, 22, 2, 225-247. \& Oddou, G. 1991. Toward a Comprehensive Model of International Adjustment: An Integration of Multiple Theoretical Perspectives. Academy of Management Review, 16, 291-317.

Boyacigiller, N. 1990. The Role of Expatriates in the Management of Interdependence. Journal of International Business Studies, 21(3): 357-381. 
Kleinberg, M.J., Philips, M \& Sackmann, S. 1996. Conceptualizing Culture. In B.J.Punnett \& O.Shenkar, Handbook for international Management Research. Cambridge, MS: Blackwell.

Brewster, C. 1995. Effective Expatriate Training. In Selmer, J. (Editor), Expatriate Management: New Ideas for International Business. Westport, CN: Quorum.

Brown, L. T., Rugman, A. M. \& Verbeke, A. 1989. Japanese Joint Ventures with Western Multinationals: Synthesizing the Economic and Cultural Explanations of Failure. Asia Pacific Journal of Management, 6: 225-242.

Buckley, P.J. \& M. Casson. 1976. The Future of the Multinational Enterprise. London: MacMillan.

\& 1979. A Theory of International Operation. In J. Leontiades \& M. Ghertman (eds), European Research in International Business. Amsterdam/London: North-Holland.

Caves, R.E. \& Mehra, S.K. 1986. Entry of Foreign Multinationals into U.S. Manufacturing Industries. In Michael E. Porter, editor, Competition in Global Industries. Boston: Harvard Business School.

Chang, S.J. 1995. International Expansion Strategy of Japanese Firms: Capability Building through Sequential Entry. Academy of Management Journal, 38, 383-407.

Cho, K.R. \& P. Padmanabhan. 1995. Acquisition Versus New Venture: The Choice of Foreign Establishment Mode by Japanese Firms. Journal of International Management, 1(3): 255-285.

Chowdhury, J. 1992. Performance of International Joint Ventures and Wholly Owned Foreign Subsidiaries: A Comparative Perspective. Management International Review, 32(2): 115-133.
Davidson, W.H. 1980. The Location of Foreign Direct Investment Activity: Country Characteristics and Experience Effects. Journal of International Business Studies, 11, 2, 9-22.

\& McFeteridge, D.J. 1985. Key Characteristics in the Choice of International Technology Transfer Mode. Journal of International Business Studies, 16 (Summer), 5-22. 1980. The Location of Foreign Direct Investment Activity: Country Characteristics and Experience Effects. Journal of International Business Studies, 11, 2, 9-22.

Dickson, P.H. \& Weaver, K.M. 1997. Environmental Determinants and Individual-Level Moderators of Alliance Use. Academy of Management Journal, 40, 2, 404-425.

Drenth, P.J.D. 1983. Cross-Cultural Organizational Psychology: Challenges and Limitations. In Irvine, S.H., \& Berry, J.W. (Eds.), Human Assessment and Cultural Factors. NY: Plenum press.

Dubin, M. 1975. Foreign Acquisitions and the Spread of the Multinational Firm. D.B.A. thesis, Graduate School of Business Administration, Harvard University.

Dunning, J.H. 1988. The Eclectic Paradigm of International Production: A Restatement and Some Possible Extensions. Journal of International Business Studies, 19, 1-31.

Engwall, L. 1984 (ed.). Uppsala Contributions to Business Research. Uppsala, Sweden: Acta Universitatis Upsaliensis.

\& Wallenstal, M. 1988. Tit for Tat in Small Steps: The Internationalization of Swedish Banks. Scandinavian Journal of Management, 4(3/4):147155.

Erramilli, M.K. 1991. The Experience Factor in Foreign Market Entry Behav- 
ior of Service Firms. Journal of International Business Studies, 22(3): 479501.

1996. Nationality and Subsidiary Patterns in Multinational Corporations. Journal of International Business Studies, 27, 225-248.

\& C.P. Rao. 1993. Service Firms' International Entry Mode Choice: A Modified Transaction-Cost Analysis Approach. Journal of Marketing, 57(July): 19-38.

Finkelstein, S. 1992. Power in Top Management Teams: Dimensions, Measurement, and Validation. Academy of Management Journal, 35: 505-538.

Forgsren, M. 1989. Managing the Internationalization Process: The Swedish Case. London, UK: Routledge.

Gatignon, H. \& E. Anderson. 1988. The Multinational Corporation's Degree of Control Over Foreign Subsidiaries: An Empirical Test of a Transaction Cost Explanation. Journal of Law, Economics, and Organization, 4(2): 305-336.

Geringer, J.M. 1998. Assessing Replication and Extension. A Commentary on Glaister and Buckley: Measures of Performance in UK International Alliances. Organization Studies, 19, 1, 119-138.

Gomes-Casseres, B. 1989. Ownership Structures of Foreign Subsidiaries: Theory and Evidence. Journal of Economic Behaviour and Organization, 11: 1-25.

Gomez-Mejia, L.R. \& Palich, L. 1997. Cultural Diversity and the Performance of Multinational Firms. Journal of International Business Studies, 309335.

Goodnow, J.D. \& Hanz, J.E. 1972. Environmental Determinants of Overseas Market Entry Strategies. Journal of International Business Studies, 3, 33-50.
Goodstein, L. D. \& Hunt, J.W. 1981. Commentary: Do American theories Apply Abroad? Organizational Dynamics, 10(1): 49-62.

Gould, P. 1966. On Mental Maps. Discussion paper No 9, Department of Geography, University of Michigan.

Hamel, G., Doz, Y.L. \& Prahalad, C.K. 1989. Collaborate with Your Competitors-And Win. Harvard Business Review, 67(1): 133-139.

Harrigan, K.R. 1985. Strategies for Joint Ventures. Lexington, MA: Lexington Books.

1988. Strategic Alliances and Partner Asymmetries. In F.J. Contractor \& P. Lorange (eds.). Cooperative Strategies in International Business. Lexington, MA: Lexington Books, 205226.

Haspeslagh, P. C. \& Jemison, D. B. 1991. Managing Acquisitions: Creating Value Through Corporate Renewal. New York: Free Press.

Hennart, J-F. 1991. The Transaction Costs Theory of Joint Ventures: An Empirical Study of Japanese Subsidiaries in the United States. Management Science 37(4): 483-497.

Hergert, M. \& D. Morris. 1988. Trends in International Collaborative Agreements. In F.J. Contractor \& P. Lorange (eds.). Cooperative Strategies in International Business. Lexington, MA: Lexington Books, 99-110.

Hofstede, G. 1980. Culture's Consequences. New York: Sage.

1989. Organizing for Cultural Diversity. European Management Journal, 7(4): 390-397.

\& Bond, M.H. 1988. The Confucius Connection: From Cultural Roots to Economic Growth. Organizational Dynamics, 16(4): 4-21.

Neuijen, B., Ohavy, D. D., and Sanders, G. 1990. Measuring Organiza- 
tional Cultures: A Qualitative and Quantitative Study Across Twenty Cases. Administrative Science Quarterly, 35: 386-316.

Huber, G.P. \& Power, D.J. 1985. Retrospective Reports of Strategic Level Managers: Guidelines for Increasing their Accuracy. Strategic Management Journal, 6: 171-180.

Johanson, J. \& J.E. Vahlne. 1977. The Internationalization Process of the Firm: A Model of Knowledge Development and Increasing Foreign Market Commitments. Journal of International Business Studies, 8(Spring/Summer): 23-32.

\& F. Wiedersheim-Paul. 1975. The Internationalization of the Firm: Four Swedish Cases. Journal of Management Studies, 12(3): 305-322.

Johnson, J. L., Cullen, J. B. \& Sakano, T. 1991. Cultural Congruency in International Joint Ventures: Does it Matter? Proceedings of the Eastern Academy of Management Fourth Biennial International Conference, Nice, France (June).

Kim, W.C. \& Hwang, P. 1992. Global Strategy and Multinational Entry Mode Choice. Journal of International Business Studies, 23, 1, 29-53.

Kogut, B. \& Singh, H. 1988. The Effect of National Culture on the Choice of Entry Mode. Journal of International Business Studies, 19(3): 411-432.

Larimo, J. 1993. Foreign Direct Investment Behaviour and Performance: An Analysis of Finnish Direct Manufacturing Investments in OECD countries. Acta Wasaensia, no. 32. Faasa, Finland: University of Vaasa.

Laurent, A. 1986. The Cross-Cultural Puzzle of International Human Resource Management. Human Resource Management, 25, 1, 91-102.
Li, J.T. \& S. Guisinger. 1991. Comparative Business Failures of Foreign-Controlled Firms in the United States. Journal of International Business Studies, 22(2): 209-224.

Lorange, P. \& J. Roos. 1991. Why Some Strategic Alliances Succeed and Others Fail. The Journal of Business Strategy, (January/February): 25-30.

Luostarinen, R. 1980. Internationalization of the Firm. Helsinki: The Helsinki School of Economics.

Mariotti, S. \& Piscitello, L. 1995. Information Costs and Location of FDIs Within the Host Country: Empirical Evidence from Italy. Journal of International Business Studies, 26, 4, 815841.

Morgan, G. 1986. Images of Organization. Beverly Hills: Sage Publications.

Morosini, P. 1998. Managing Cultural Differences. UK: Pergamon.

Nahavandi, A. \& Melekzadeh, A. 1988. Acculturation in Mergers and Acquisitions. Academy of Management Review, 13, 79-90.

O'Grady, S. \& Lane, H.W. 1996. The Psychic Distance Paradox. Journal of International Business Studies, 27, 2, 309-333.

Ozawa, Terutomo. 1979. International Investment and Industrial Structure: New Theoretical Implications from the Japanese Experience. Oxford Economic Papers, 31, 1, 72-92.

Padmanabhan, P. \& Cho, K.R. 1994. Ownership Strategy for a Foreign Affiliate: An Empirical Investigation of Japanese Firms. Management International Review, 36(1): 45-65.

Pan, Y. 1996. Influences on Foreign Equity Ownership Level in Joint Ventures in China. Journal of International Business Studies, 77, 1,1-26.

Park, S.H. \& Ungson, G.R. 1997. The Effect of National Culture, Organiza- 
tional Complementarity, and Economic Motivation on Joint Venture Dissolution. Academy of Management Journal, 40, 2, 279-307.

Parkhe, A. 1991. Interfirm Diversity, Organizational Learning, and Longevity in Global Strategic Alliances. Journal of International Business Studies, 22(4): 579-600.

Richman, B.M. \& Copen, M. 1972. International Management and Economic Development NY: McGrawHill.

Ronen, S. \& Shenkar, O. 1985. Clustering Countries on Attitudinal Dimensions: A Review and Synthesis. Academy of Management Review, 10,3,435-454.

Root, F. 1987. Entry Strategies for International Markets. Lexington, MA: Lexington Books.

Roth \& O'Donnell. 1996. Foreign Subsidiary Compensation Strategy: An Agency Theory Perspective. Academy of Management Journal, 39(3): 678-703.

Sackmann, S.A. 1983. Organizationskltur-Die Unsichtbare Einflussgrosse (Organizational Culture-The Invisible Influence). Gruppendynamick, 14:393406.

Sales, M.S. \& Mirvis, P.H. 1984. When Cultures Collide: Issues in Acquisitions. In J.R. Kimberly \& R.E. Quinn (Eds), Managing Organizational Transitions. Homewood, IL: Irwin.

Schneider, S.C. 1988. National vs. Corporate Culture: Implications for $\mathrm{Hu}$ man Resource Management. Human Resource Management, 27: 231-246.

Schwartz, S.H. \& Bilsky, W. 1990. Toward a Theory of the Universal Content and Structure of Values: Extensions and Cross-Cultural Replications. Journal of Personality and Social Psychology, 58(5): 878-891.
1994. Beyond Individualism/ Collectivism: New Cultural Dimensions of Values. Individualism and Collectivism: Theory, Method, and Applications (p. 85-119). Sage Publications Inc, Thousand Oaks, CA.

Shane, S.A. 1992. The Effect of National Cultural Differences in Perceptions of Transaction Costs on National Differences in the Preferences for Licensing. Academy of Management Best Papers Proceedings.

Shenkar, O. 1992. The Corporate/National Culture Matrix in International Joint Ventures. Paper presented at the AIB annual meeting. Brussel, Belgium. and Zeira, Y. 1992. Role Conflict and Role Ambiguity of Chief Executive Officers in International Joint Ventures. Journal of International Business Studies, Vol. 23: 55-75.

Stopford, J.M. \& L.T. Wells Jr. 1972. Managing the Multinational Enterprise: Organisation of the Firm and Ownership of the Subsidiaries. New York: Basic Books.

Sullivan, D. \& Bauerschmidt, A. 1990. Incremental Internationalization: A Test of Johanson and Vahlne's Thesis. Management International Review, 30, 19-30.

Tallman, S. B. 1988. Home Country Political Risk and Foreign Direct Investment. Journal of International Business Studies, 19(2): 219-234.

\& Shenkar, O. 1994. A Managerial Decision Model of International Cooperative Venture Formation. Journal of International Business Studies, 25(1), 91-114

Thunnell, L. H. 1977. Political Risk in International Business. NY: Praeger.

Turnbull, P.W. 1987. A Challenge to the Stages Theory of the Internationalization Process. In Reid, S./Rosson, P. (eds.). Managing export entry and ex- 
pansion, New York: Praeger, p.p. 2140.

Vachani, S. 1991. Distinguishing Between Related and Unrelated International Geographic Diversification: A Comprehensive Measure of Global Diversification. Journal of International Business Studies, 22(2): 307-322.

Veiga, J., Lubatkin, M., Calori, R. \& Very, P. 2000. Measuring Organizational Culture Clashes: A Two-Nation PostHoc Analysis of Cultural Compatibility Index. Human Relations, 53, 4, 539-557.

Calori, R., Very, P. \&

Tung, Y.A. 2000. Using Neutral Network Analysis to Uncover the Trace Effects of National Culture. Journal of International Business Studies, 31,2, 223-238.
Webber, R. 1969. Convergence or Divergence? Columbia Journal of World Business, 4, 3.

Weber, Y., Shenkar, O. \& Raveh, A. 1996. National and Corporate Cultural Fit in Mergers/Acquisitions: An Exploratory Study. Management Science, 42, 8, 1215-1227.

Welch, L.S. \& Luostarinen, R. 1988. Internationalization: Evolution of a Concept. Journal of General Management. 14, 2, 34-55.

Williamson, O. 1985. The Economic Institutions of Capitalism. New York: The Free Press.

World Competitiveness Yearbook. 2000. Yoshino, Michael Y. 1976. Japan's Multinational Enterprises. Cambridge, MS: Harvard University Press. 